\title{
The Philosophy of Error and Liberty of Thought: J.S. Mill on Logical Fallacies
}

\section{Frederick Rosen}

\author{
University College London
}

\begin{abstract}
Most recent discussions of John Stuart Mill's System of Logic (1843) neglect the fifth book concerned with logical fallacies. Mill not only follows the revival of interest in the traditional Aristotelian doctrine of fallacies in Richard Whately and Augustus De Morgan, but he also develops new categories and an original analysis which enhance the study of fallacies within the context of what he calls 'the philosophy of error'. After an exploration of this approach, the essay relates the philosophy of error to the discussion of truth and error in chapter two of On Liberty (1859) concerned with freedom of thought and discussion. Drawing on Socratic and Baconian perspectives, Mill defends both the traditional study of logic against Jevons, Boole, De Morgan, and others, as well as the study of fallacies as the key to maintaining truth and its dissemination in numerous fields, such as science, morality, politics, and religion. In Mill's view the study of fallacies also liberates ordinary people to explore the truth and falsity of ideas and, as such, to participate in society and politics and develop themselves as progressive beings.
\end{abstract}

\begin{abstract}
Résumé: Les discussions les plus récentes sur le Systems of Logic (1843) de John Stuart Mill négligent le cinquième livre, qui traite des sophismes. Mill suit non seulement la reprise d'intérêt dans la doctrine aristotélicienne traditionnelle de Richard Whately et d'Augustus DeMorgan, mais développe aussi des nouvelles catégories et une analyse originale qui améliore l'étude des sophismes dans le contexte de ce qu'il appelle «la philosophie de l'erreur». J'explore cette approche, et ensuite je relie la philosophie de l'erreur à la discussion de la vérité et de l'erreur dans le deuxième chapitre de $O n$ Liberty (1859) qui traite de la liberté de pensée et de discussion. Mill s'inspire des perspec-tives de Socrate et de Bacon pour défendre l'étude traditionnelle de la logique contre Jevons, Boole, DeMorgan, et d'autres, ainsi que l'étude des sophismes comme moyen clé pour maintenir la vérité et sa dissémination dans plusieurs champs, tels que la science, la moralité, la politique, et la religion. Selon Mill, l'étude des sophismes libère les gens ordinaires à explorer la vérité et la fausseté des idées, à participer dans la société et la politique, et à s'instruire.
\end{abstract}

Keywords: John Stuart Mill, philosophy of error, fallacies, liberty of thought, truth, history of logic, Bacon, Socrates, Aristotle

\section{I}

Logic lays down the general principles and laws of the search after truth; the conditions which, whether recognised or not, must actually have been observed if the mind has done its work rightly. Logic is the intellectual 
complement of mathematics and physics. Those sciences give the practice, of which Logic is the theory. It declares the principles, rules, and precepts, of which they exemplify the observance.

Of Logic I venture to say, even if limited to that of mere ratiocination, the theory of names, propositions, and the syllogism, that there is no part of intellectual education which is of greater value, or whose place can so ill be supplied by anything else. Its uses, it is true, are chiefly negative; its function is, not so much to teach us to go right, as to keep us from going wrong. But in the operations of the intellect it is so much easier to go wrong than right; ... Logic points out all the possible ways in which, starting from true premises, we may draw false conclusions.

Logic is the great disperser of hazy and confused thinking: it clears up the fogs which hide from us our own ignorance, and make us believe that we understand a subject when we do not.

To those who think lightly of school logic, I say, take the trouble to learn it. You will easily do so in a few weeks, and you will see whether it is of no use to you in making your mind clear, and keeping you from stumbling in the dark over the most outrageous fallacies (CW XXI: 238, 239).

These brief passages have been taken from a discussion of logic in J.S. Mill's Inaugural Address Delivered to the University of St. Andrews (1867) (CW XXI: 215-57). They contain not only advice to young students as to how to pursue their studies but also allusions to his own intellectual development. ${ }^{1}$ Here we find a restatement of his belief in the role of logic in the search for truth, the relationship between logic and other sciences like mathematics and physics, his Socratic belief in looking into and through 'the fogs which hide us from our own ignorance', and his acceptance of Aristotelian scholastic logic with its emphasis on avoiding 'stumbling in the dark over the most outrageous fallacies'.

Mill's major work on logic, A System of Logic, Ratiocinative and Inductive (1843) (CW VII, VIII) is not as carefully studied nowadays as are his more accessible works, On Liberty (1859) (CW XVIII: 213-310) and Utilitarianism (1861) (CW $\mathrm{X}:$ 203-39). Despite this recent neglect, there is a considerable body of philosophical literature which concentrates on the Logic, as, for example, in the work of Jackson, Anschutz, Ryan, Skorupski, and Scarre, to name a few. ${ }^{2}$ Unfortunately, none of these commentators have taken much, if any, notice of the fifth book of the Logic, which is a substantial essay concerned with fallacies (CW VIII: 733-830). Yet, as we have seen in the passages quoted above, Mill seemed to place the detection of fallacies at the heart of the study of logic.

At the time Mill wrote the Logic, the inclusion of material on fallacies was somewhat contentious. That the study of fallacies (though often rejected in the 
modern period) persisted in the early part of the nineteenth century was due to the influence of Aristotelian logic, and, particularly, the influence of Aristotle's On Sophistical Refutations (Aristotle 1955: 10-155). That this study of dialectical argument should accompany the main demonstrative or didactic arguments centred on the syllogism ensured forever, it seemed, that the study of fallacies should form part of logic generally. The scholastic tradition in logic, still followed in English universities in the eighteenth and early-nineteenth centuries and enshrined in the textbooks of Robert Sanderson and Henry Aldrich, faithfully repeated the Aristotelian list of thirteen fallacies. ${ }^{3}$ Instruction in fallacies was doubtless regarded as light and often amusing relief from the otherwise tedious study of the syllogism.

Many modern philosophers, however, had followed their rejection of Aristotelian philosophy generally with a rejection or severe curtailment of the usual treatment of fallacies. Locke's Essay Concerning Human Understanding, for example, not only failed to consider the traditional list of fallacies, but also contained a critique of Aristotle and of the relevance of the syllogism as the instrument of reason and source of knowledge (Locke 1975: 671 [IV.XVII.4]). Traditional logic, for Locke, was regarded as productive only of useless disputes, which were of little benefit to society. 'For notwithstanding these learned Disputants, these all-knowing Doctors', he wrote, 'it was to the unscholastick Statesman that the Governments of the World owed their Peace, Defence, and Liberties; and from the illiterate and contemned Mechanic (a Name of Disgrace) that they received the improvements of useful Arts' (Locke 1975: 495 [III.X.9]). For Locke, and for others in the eighteenth and nineteenth centuries, the study of problems in logic, and, particularly, those that concentrated on the syllogism, tended to be translated into the study of language and/or psychology. In this development (and Locke's Essay is a good example) the traditional exposition of fallacies was omitted, as contributing more to disputes and their enjoyment than to the acquisition of knowledge.

In contrast with the example of modern philosophers rejecting Aristotelian logic and the study of fallacies, as derived from the Sophistical Refutations, Mill, as we have seen, fully embraced the traditional study of fallacies. This somewhat unusual starting point for a nineteenth-century philosopher with thoroughly progressive views owed a good deal to Richard Whately's Elements of Logic (1826) (see Whately 1975). Whately sought to revitalize the study of logic at Oxford by restating Aristotelian logic in a new context, and, in the process, abandoned what seemed to be the list of Aristotelian fallacies in favour of a new schema. The underlying momentum for the new context might be described as Coleridgean. Whately's Elements of Logic and companion work, Elements of Rhetoric (1827) (see Whately 1828), were first published in the Encyclopaedia Metropolitana, a work inspired by Coleridge to advance progressive views which could be seen as emerging out of traditional thought and institutions (see Encyclopaedia Metropolitana 1845: i.143, 193-240, 241-303). Whately's return to Aristotelian logic, set forth in a contemporary context with modern examples and without the baggage of 
scholasticism, seemed to be an ideal expression of this vision. ${ }^{4}$ I have discussed Mill's encounter with Whately's Elements of Logic and his essays on 'Bentham' (1838) (CW X: 75-115) and 'Coleridge' (1840) (CW X: 117-63) elsewhere (see Rosen 2006, 2007a, 2007b), and will simply note here that Mill's two essays on the leading British thinkers of the age were written and published at the same time (between 1838 and 1840) as the book on fallacies in the Logic was drafted and completed (CW VII: xcviii-xcix). Mill's retention and development of the study of logical fallacies was linked to his enthusiasm for the belief that the contrary ideas of Bentham and Coleridge might be successfully combined in thought and debate.

There were other factors which might have led Mill to turn to and develop the traditional study of logical fallacies. Jeremy Bentham's Book of Fallacies was published in 1824, and Bentham claimed that he was in certain respects the first person since Aristotle to reconsider the forms of logical fallacies (Bentham 1824: 2). Although Bentham was strongly criticized by Whately for the one-sidedness of his radicalism (rather than for his treatment of fallacies), Mill thought that Whately was 'unnecessarily severe' in his criticisms (see Whately 1975: 194n-5n; CW XI: 31). As we shall see, Mill also adopted one category from Bentham's work. However, Mill never fully endorsed Bentham's study of fallacies and tended to ignore it, as well as George Bentham's elaborate discussion of fallacies based on it (see G. Bentham 1827: 220ff). A more general and pervasive influence of Bentham on Mill's treatment of fallacies might be found in the conceptions of evidence developed by Bentham in the Rationale of Judicial Evidence (1827), edited by Mill (see Bentham 1827; Kubitz 1932: 51-2).

Mill also might have claimed the authority of Francis Bacon for his approach to traditional logic. Although many philosophers believed that Bacon was the champion of the rejection of the syllogism and of Aristotelian logic generally in favour of a rigorous inductive approach, Mill saw in Bacon a forerunner of his own position that sought to combine induction with syllogistic logic (CW XI: 12-13). Bacon argued that, even though traditional logic "has done more to fix errors than to reveal truth', there was no reason to attack traditional logic or even to challenge the ancient view of logic, as the new inductive system could easily exist side by side with the Aristotelian system (Bacon 1994: 38). 'Let there be therefore, as a boon and blessing for each side, two sources of knowledge and two ways of organizing it; and likewise two tribes of thinkers and philosophers, two clans as it were, not in any way hostile or alien to each other, but linked in mutual support .. ..' (Bacon 1994: 40). Furthermore, Mill's discussion of error, as we shall see, owed a good deal to Bacon's analysis of 'Idols', and, particularly, to 'Idols of the Theatre' in the Novum Organum.

Another factor that lay behind Mill's study of fallacies was his commitment to a Socratic method in philosophy (see Urbinati 2002: 142-3). Mill had been attracted to Socrates, his hero and mentor, from his earliest days. 'The Socratic method', he wrote in the 'Early Draft' of the Autobiography, '. . . is unsurpassed as a 
discipline for abstract thought on the most difficult subjects. Nothing in modern life and education, in the smallest degree supplies its place' (CW I: 24). After a brief account of the Socratic elenchus, he concluded that, even as a boy, the Socratic method 'took such hold on me that it became part of my own mind; and I have ever felt myself, beyond any modern that I know of except my father and perhaps beyond even him, a pupil of Plato, and cast in the mould of his dialectics' (CW I: 24). Mill wrote his translations and brief comments on nine Platonic dialogues for the Monthly Repository in 1834-5 (see CW XI: 37-238), just prior to his writing the essays on Bentham and Coleridge and the fifth book of the Logic. He also would have known that in the Sophistical Refutations Aristotle was reflecting and consolidating the earlier debates between Socrates and the Sophists and others, which appear in these dialogues.

Mill was strongly impressed by Plato's picture in the Gorgias and Republic 'of the solitary and despised position of the philosopher in every existing society, and the universal impression against him, as at best an useless person, but more frequently an eminently wicked one'... (CW XI: 399). He adopted Grote's arguments that while Plato might have despised the Sophists, because they were more concerned with appearances than with reality, and took money for their services, they were not the real enemy.The real corruptors of the young were not the Sophists, but society itself:

... their families, their associates, all whom they see and converse with, the applauses and hootings of the public assembly, the sentences of the court of justice. These are what pervert young men, by holding up to them a false standard of good and evil, and giving an entirely wrong direction to their desires. As for the Sophists, they merely repeat the people's own opinions. (CW XI:400)

Mill not only adopted Grote's view of the importance of the Sophists to public debate and the role of Socrates in this debate, but, in a review of Grote's posthumously published study of Aristotle, he also acknowledged the importance of the Sophistical Refutations in the development of an important aspect of logic and in the pursuit of truth. Even though Aristotle's work was a study of the art of arguing for victory rather than for truth, Mill saw nothing wrong with such public debates so long as they took place within established rules. Furthermore, he believed that Aristotle regarded such exercises in dialectical argument to be valuable in the pursuit of truth. Quoting from Grote, Mill gave three reasons for this belief (CW XI: 508). First, the debates constituted a kind of mental exercise that was valuable and stimulating. Second, the debates put one in touch with the ordinary opinions held by society, and hence led the philosopher to attempt to understand and modify them. Third, such dialectical debate influenced science and philosophy, encouraging one to look at both sides of questions and to determine which answers were true or false. Mill believed that Aristotle's method in dialectical argument 'was greatly in advance not only of his own time, but of ours': 
His general advice for exercise and practice in Dialectic is admirably adapted to the training of one's own mind for the pursuit of truth. "You ought to test every thesis by first assuming it to be true, then assuming it to be false, and following out the consequences on both sides." This was already the practice of the Eleatic dialecticians, as we see in the Parmenides. (CW XI: 508)

Mill's study of fallacies was based on the lonely philosophical mission of Socrates and the framework of Aristotle's various categories of fallacies provided by generations of logicians. He proposed a major revision of the Aristotelian categories without rejecting Aristotle's achievement and without abandoning the perspective of the Socratic dialectician on which it was based.

\section{II}

Mill's analysis of fallacies was intended to form part of what he called the 'Philosophy of Error' (CW VIII: $\left.737[\mathrm{~V} \mathrm{i} \S 3]^{5}\right)$. This phrase may seem strange to us, though it would not have been odd for Mill to use it. At the beginning of the book on fallacies, Mill quoted briefly from Malebranche and Hobbes, both of whom wrote on the theme of error (see CW VIII: 734; intro. quotation). Malebranche, for example, began his The Search after Truth as follows:

Error is the cause of men's misery; it is the sinister principle that has produced the evil in the world; it generates and maintains in our soul all the evils that afflict us, and we may hope for sound and genuine happiness only by seriously laboring to avoid it. (Malebranche 1997:1)

For Malebranche, the main source of error was not one that lay outside the individual, but was closely connected with the misuse of freedom. This misuse of freedom consisted of a failure to regulate the will in its eagerness to embrace the truth. Such eagerness led one to embrace the appearance of truth and to go beyond the understanding to judge of matters and give consent to the truth of propositions about which one had no clear perception (Malebranche 1997: 16).

According to Hobbes, we might distinguish between falsity and error. Falsity arose from 'pronouncing rashly', as when in seeing the sun in the sky and its reflection in the water we say that both are the sun and then conclude that there are two suns. Such a false conclusion was represented by Hobbes as a departure from the agreed conventions of names and not the commission of error. Error arose from our senses and thinking, as, for example, when we saw the sun's reflection in the water, we imagined that it was actually there (Hobbes 1997: i.556). The deception here, as in Malebranche, proceeded from within the individual, even though Hobbes did not subscribe to the doctrine of freedom of the will. For Hobbes, error was a deception, to which we consented, that proceeded from reasoning itself. Such an error was further distinguished from absurdity ('senseless speech'), as when one referred to a round triangle, etc., which was nonsense rather than error (though often commonly referred to as error) (see Hobbes 1997: iii.32). 
For both Malebranche and Hobbes, error could be combated by the individual through the exercise of freedom of thought and the use of reason. However, not all philosophers accepted this position. Locke, for example, included a chapter 'Of Wrong Assent, or Error' (IV.XX) in the Essay, which seemed to diminish the scope of freedom and the occasions for error, leading him to the paradoxical conclusion that 'There are not so many Men in Errours and wrong Opinions, as is commonly supposed' (Locke 1975: 719). The conclusion was paradoxical not because Locke believed that we generally knew the truth, but despite our ignorance, we did not actually make erroneous judgments. For most ordinary people the need to labour left them unable to consider the validity of the proofs of arguments to establish whether or not they were erroneous or true (Locke 1975: 706ff). For those who had leisure, Locke found them 'confined to narrowness of Thought, and enslaved in that which should be the freest part of Man, their Understandings.' Required religious observance, it seemed, supplied the opinions of the leisured few, and filled up the minds of those who had only a little leisure from the drudgeries of labour. Locke referred to this phenomenon as the propagation of 'Truth without Knowledge', 'where Men are forced, at a venture, to be of the Religion of the Country; and must therefore swallow down Opinions, as silly People do Empiric's Pills, without knowing what they are made of, or how they will work, and have nothing to do, but believe that they will do the Cure. .' (Locke 1975: 708-9). Furthermore, most people could not follow a syllogism or other process of reasoning and in this respect 'there is a greater distance between some Men, and others. . . than between some Men and some Beasts' (Locke 1975: 709). Others did not wish to cultivate the understanding due to weakness of will, the 'hot pursuit of pleasure', drudgery in their business and domestic lives, laziness, oscitancy, an aversion to books and study, and simply took on trust what they found convenient and 'in fashion'. They also tended to care for their bodies but not for their souls (Locke 1975: 710).

Logic and hence fallacies, for Locke, thus played a small role in the lives of most people. As Locke wrote:

'Tis enough for him to obey his Leaders, to have his Hand and his Tongue ready for the support of the common Cause, and thereby approve himself to those, who can give him Credit, Preferment, or Protection in that Society. Thus Men become Professors of, and Combatants for, those Opinions, they were never convinced of, nor Proselytes to; no, nor even had so much as floating in their Heads: and though one cannot say, there are fewer improbable or erroneous Opinions in the World than there are; yet this is certain, there are fewer, that actually assent to them, and mistake them for truths, than is imagined. (Locke 1975: 719)

If Locke seemed to provide little scope for the work of the individual logician, and no estimation of that interior freedom apparently necessary to detect errors in reasoning, Mill certainly did. For Mill, however, not all errors were relevant to the study of fallacies. He would not include casual mistakes, such as the incorrect 
addition of a sum, the remedies for which would be simply paying greater attention and further practice (CW VIII: 736-7 [V i §2]). Nor did he include moral (as opposed to intellectual) sources of erroneous opinions, which were due to indifference to attaining truth on the one hand and bias on the other. Both of these were highly powerful and influential, but, in Mill's opinion, they could not operate on their own. They predisposed one to erroneous opinions, but did not actually determine them. Indifference to the truth led to error, because it prevented the mind from collecting evidence and making careful inductions. Bias would dispose the mind towards accepting erroneous theories, but would not in itself lead to errors (CW VIII: 737-8 [V i §3]).

This analysis of the human condition led Mill to an apparently gloomy conclusion regarding philosophical theories:

The natural or acquired partialities of mankind are continually throwing up philosophical theories, the sole recommendation of which consists in the premises they afford for proving cherished doctrines, or justifying favourite feelings: and when any one of these theories has been so thoroughly discredited as no longer to serve the purpose, another is always ready to take its place. (CW VIII: 738 [V i §3])

This apparently endless succession of false and misleading philosophical theories is bad enough, but to make matters worse, those who attempted to use their intelligence to gather and assess evidence and make inferences from such evidence were often 'stigmatised' with names like 'scepticism, immorality, coldness, hardheartedness, and similar expressions' (CW VIII: 738 [V i §3]).

In spite of this view of the human condition Mill believed that whenever bias operated successfully, it was first necessary to undermine the understanding. Anyone sufficiently on guard regarding evidence and inference would be able to resist such subverting pressures of bias. As he wrote:

There are minds so strongly fortified on the intellectual side, that they could not blind themselves to the light of truth, however really desirous of doing so; they could not, with all the inclination in the world, pass off upon themselves bad arguments for good ones. (CW VIII: 739 [V i §3])

Mill thus proposed an opposing force of the incorruptible intellect that could withstand the presence and influence of bias. There were a few people who could resist the appeal of bias and both the illusions and enticements of fashionable philosophical theories. 'If the sophistry of the intellect could be rendered impossible', Mill wrote, 'that of the feelings, having no instrument to work with, would be powerless' (CW VIII: 739 [V i §3]). He did not propose a campaign to eliminate bias; that would have been impossible. Bias was derived from human nature itself. One might have concluded that the inevitability of the succession of one false but fashionable theory after another meant that we were condemned to live wholly in a world of false consciousness. But, as we have seen, Mill allowed full scope for the search for truth in all fields where the intellect might bring enlightenment. 
Logic itself would enable truth to be discovered and maintained across all subjects, but the study of fallacies had a special role. It not only supported the pursuit of truth, but it equally could be used to undermine this apparently endless succession of bogus philosophy based on bias and an indifference to truth. Even though new theories might be waiting in the wings to succeed those discredited by philosophical analysis, the philosophy of error itself might develop and become more widespread, thus limiting the effect of these fashionable theories. For Mill, then, the study of fallacies provided an important ally for philosophical analysis in preparing the mind and assisting in the development of mental habits that protected the individual and enabled one more easily to detect error.

Although Mill's contribution to the 'Philosophy of Error' is striking, it is not necessarily original. His depiction of the succession of erroneous philosophical theories might well have been taken from Bacon's 'Idols of the Theatre' in the Novum Organum (Bacon 1994: 55-6; see Urbach 1987: 105-6). Bacon's depiction of the 'various dogmas of philosophies' as 'so many stage plays creating fictitious and imaginary worlds' must surely have been Mill's source for his own striking vision of the endless succession of false philosophical theories.

In addition to Bacon, one should also mention the Port-Royal Logic of Arnauld and Nicole, which Mill generally regarded favourably (see Arnauld and Nicole 1996: 135, 189-203ff). Here one can find an account of fallacies that included, but also looked beyond, the Aristotelian list. The discussion of error sought to account for how one acquired false principles as much as, following Aristotle, how one reasoned incorrectly from these principles. Like Arnauld and Nicole, Mill was also concerned with how self-love, interest, or passion might lead one to adopt various principles, and he was also willing to take up the challenge of understanding such influences or thought from the perspective of fallacious reasoning.

Mill's discussion of the philosophy of error fed into his other writings on numerous levels. To take one example, it enables us to appreciate more fully his analysis of 'Of the Liberty of Thought and Discussion'- the title and topic of Chapter 2 of On Liberty (CW XVIII: 228). This chapter, usually referred to in terms of freedom of expression or freedom of opinion, contains two elements with which freedom is concerned: thought and discussion. It is clear from the opening paragraphs that Mill's philosophy of error was lurking in the background. The pursuit of truth, which liberty would facilitate, was inconceivable for Mill without the presence and beneficial use of error. If liberty was denied, an erroneous opinion could not be exchanged for a true one; but if an original opinion was true, the denial of liberty meant that one could not benefit from 'the clearer perception and livelier impression of truth, produced by its collision with error' (CW XVIII: 229 [ $L$ ii para.1]). The study of fallacies was one important way of encouraging the beneficial dialogue between truth and error, which enabled truth ultimately to replace error in inference, deduction, and in argument generally. 
Mill also repeated in On Liberty his belief that error could be corrected (CW XVIII: 231 [ $L$ ii para.7]), but there were new elements in his argument that were not present in the Logic. On the one hand, consistently with the Logic, he could write:

It is a piece of idle sentimentality that truth, merely as truth, has any inherent power denied to error, of prevailing against the dungeon and the stake. Men are not more zealous for truth than they often are for error, and a sufficient application of legal or even social penalties will generally succeed in stopping the propagation of either (CW XVIII: 238-9 [ $L$ ii para.17]).

Although Mill continued by qualifying his remarks, he provided here, as in the Logic, no assurance that truth would triumph over error. At one point he also alluded to the tiny minority concerned with truth in any society and the near impossibility of struggling against error among this elite:

... for, on any matter not self-evident, there are ninety-nine persons totally incapable of judging of it, for one who is capable; and the capacity of the hundredth person is only comparative; for the majority of the eminent men of every past generation held many opinions now known to be erroneous, and did or approved numerous things which no one will now justify. (CW XVIII: 231 [L ii para.7])

Not only do we see in this material an allusion to Bacon's 'Idols of the Theatre' and Mill's own use of it, but also to such great figures as Socrates and Jesus who, as individuals, died for truth (CW XVIII: 235-6 [ $L$ ii paras.12,13]). One might have expected Mill to endorse the position in the Logic regarding the struggle against the endless procession of false philosophical theories and to confirm his ringing statement in the introduction to the Logic that logic was concerned with the cultivation and development of one's own thoughts: 'If there were but one rational being in the universe, that being might be a perfect logician; and the science and art of logic would be the same for that one person as for the whole human race' (CW VII: 6 [intro. §3]).

Nevertheless, just following the passage quoted above concerning ninety-nine out of a hundred people, Mill posed a different question and gave to it a very different and apparently more optimistic answer:

Why is it, then, that there is on the whole a preponderance among mankind of rational opinions and rational conduct? If there really is this preponderance - which there must be unless human affairs are, and have always been, in an almost desperate state-it is owing to a quality of the human mind, the source of everything respectable in man either as an intellectual or as a moral being, namely that his errors are corrigible. (CW XVIII: 231 [ $L$ ii para.7])

One might admit that Mill's assertion of the preponderance of rational opinion and conduct was set forth somewhat tentatively, but still wonder how his belief that error was correctable (a belief at the heart of the philosophy of error and linked to the very idea of liberty of thought) could sustain the thesis that mankind 
was mainly rational in opinions and conduct. What happened to the moral causes of error, i.e., indifference to truth and bias that led so many to accept error?

Mill's sudden ascription of rationality to mankind reveals an important duality in On Liberty that fits together only tentatively or, we might even say, hypothetically. On the one hand, to overcome error, the great thinker must be free to follow his intellect wherever it led. The person who thought for himself or herself, and despite errors, did not give up, was superior to those who held only true opinions due to an indifference to the truth. On the other hand, Mill was not satisfied with the social consequences of what the great thinker might achieve, because this achievement might take place in a society where most people suffered mental enslavement. As Mill wrote:

Not that it is solely, or chiefly, to form great thinkers, that freedom of thinking is required. On the contrary, it is as much and even more indispensable, to enable average human beings to attain the mental stature which they are capable of. There have been, and may again be, great individual thinkers, in a general atmosphere of mental slavery. But there never has been, nor ever will be, in that atmosphere, an intellectually active people. (CW XVIII: 243 [ $L$ ii para.20])

Clearly, for Mill, in On Liberty an 'intellectually active people' was as important as that 'one rational being in the universe' of the Logic. But in On Liberty Mill also attempted to bring them together. It is important to be clear about what Mill sought to bring together. O'Rourke has argued correctly against Himmelfarb, Skorupski, and others, who see different and conflicting principles of liberty in On Liberty, with freedom of expression being primarily other-regarding, while liberty generally is mainly concerned with self-regarding acts (O'Rourke 2001: 107ff). He has also emphasized not only that freedom of thought is primarily self-regarding, but also that it is the driving force behind freedom of expression generally (O'Rourke 2001: 77ff, 96 and n). Thus, for O'Rourke, there is no conflict or inconsistency between the liberty of expression emphasized in Chapter 2 of On Liberty and the discussion of liberty generally in that work.

My problem with On Liberty is of a different kind. The development of the philosophy of error in the Logic clearly adds to and supports O'Rourke's thesis in showing what Mill meant by the very idea of liberty of thought. My problem arises from Mill's clear acceptance of the role of the great individual thinker, like Socrates, in a world that despises or rejects such a person. How then did Mill shift the argument from the great thinker to the 'average human being'? He did so by again invoking the philosophy of error. All human beings have the capacity to correct error. Indeed, if freedom of thought, and this aspect of it, provides the dynamic for the whole of On Liberty, and if such liberty is the only bulwark against the tyranny of the majority, it is no wonder that Mill remained, as we have seen from the quotations from his Inaugural Address, the great advocate of the study of logic. This study, and particularly that of fallacies, is one important way for the 
logic of a Socrates to become that of an average human being. Even if only a few can aspire to greatness in philosophy, everyone is capable of searching out and correcting error. For Mill, therefore, as evident in the Inaugural Address, the study of logic is the bedrock of the search for truth generally in any society that values liberty.

\section{III}

If some of Mill's contemporaries, like Whately and De Morgan, were content to expound, more or less, the original Aristotelian list of fallacies (see Whately 1975: 131-203; De Morgan 1926: 276ff), Mill set out an entirely new classification (CW VIII: 743 [V ii §2]). This classification ultimately created five categories with many forms illustrated within each category. Most of the Aristotelian list reappear in Mill's discussion in various ways, but Mill's aims and treatment of the fallacies were original and distinctive. A full survey of all of the fallacies might be somewhat tedious, so I shall confine myself to a general survey of his main categories and some estimation of his achievement.

Mill reached his five categories by making a series of distinctions between various kinds of belief and argument. The first category was based on a distinction between beliefs held to be true simply and without evidence and those based on inferences from evidence. Fallacies, related to the former, were called fallacies of simple inspection or a priori fallacies which were held without direct evidence or experience, but created a presumption in favour of a proposition which allowed the holder to discard rules of induction (CW VIII: 741 [V ii §2]). The six examples given by Mill covered an enormous amount of ground, and Alexander Bain thought that the category might be included in a separate treatise on its own, and, additionally, need not be the special province of the logician (Bain 1870: ii.375).

Let us look briefly at some of the fallacies Mill discussed. The first consisted of mistaking subjective laws for objective ones. This category is somewhat reminiscent of Bentham's dramatic account in An Introduction to the Principles of Morals and Legislation, much admired by Mill, of the way most previous philosophers had used subjective ideas as objective principles and foundations for their systems. Bentham mentioned, for example, such common ideas in philosophy and theology, as moral sense, common sense, understanding, rule of right, fitness of things, law of nature, law of reason, natural justice, natural equity, good order, truth, and the doctrine of election (Bentham 1996: 21ff, 26n-7n; see Rosen 2003: 221ff). Mill had a similar object in mind at the level of logic in seeking to dismiss much of what he called 'intuitionism' in favour of his own empiricism. But he believed, and expressed this belief at a number of points in the Logic (e.g. CW VII: 8-9, 14 [intro. §4]; VIII: 644 [IV i §2], 746-7 [V iii §1]), that logic could not and need not resolve metaphysical issues or determine fundamental philosophical positions. Nevertheless, the exposure of logical fallacies might undermine such positions and require those who took them to restate or abandon their arguments. 
Although Mill fully appreciated this way of thinking among intuitionist philosophers, he turned instead to illustrate the fallacy by considering several popular beliefs where subjective thoughts were wrongly given objective status. For example, he took the common remark, 'talk of the devil and he will appear', to illustrate how an idea was supposed to establish a reality (CW VIII: 748 [V iii §2]). The work of alchemists to make gold potable and exploit its miraculous properties, Mill believed, was based on the idea that because gold was considered something precious and to be marvelled at, it must have marvellous properties as a physical substance. The fallacy that wonderful events must have wonderful properties was illustrated by the example of showers of objects falling mysteriously in northern Italy being regarded as manna from heaven and eaten avidly by the local population, even though analysis revealed such manna to consist of the excrement of insects. So eagerly was the so-called manna consumed that it was difficult to obtain samples for analysis (CW VIII: 750 [V iii §3]).

Mill then went on to consider how this fallacy infected scientific and philosophical thinking. The fallacy consisted in the belief that 'our ideas of things must be true of the things themselves' (CW VIII: 751 [V iii §3]). At the level of philosophy one example was the tendency to believe that things that we think of together must exist together, and a second example: that which is inconceivable must be false (CW VIII: 750 [V iii §3]).

The first part of this fallacy (that A must accompany B because it is involved in the idea of B) was first exhibited, he believed, by Descartes, but was later taken up by Spinoza, Leibniz, and was widespread in modern German philosophy. Mill then wrote:

I am indeed disposed to think that the fallacy now under consideration has been the cause of two-thirds of the bad philosophy, and especially of the bad metaphysics, which the human mind has never ceased to produce. Our general ideas contain nothing but what has been put into them, either by our passive experience, or by our active habits of thought; and the metaphysicians in all ages, who have attempted to construct the laws of the universe by reasoning from our supposed necessities of thought, have always proceeded, and only could proceed, by laboriously finding in their own minds what they themselves had formerly put there, and evolving from their ideas of things what they had first involved in those ideas. In this way all deeply-rooted opinions and feelings are enabled to create apparent demonstrations of their truth and reasonableness, as it were out of their own substance. (CW VIII: 752 [V iii §3])

This passage has been quoted at length to show that Mill regarded any philosophy that did not engage with a rigorous empiricism as being fundamentally flawed. Although a work on metaphysics might be necessary to dispatch that particular doctrine, the analysis of fallacies was intended to undermine particular aspects of it. 
Mill illustrated the second part of this fallacy, that things that cannot be conceived together cannot exist together, by using an example taken from Isaac Newton. Newton responded to Descartes' attack on the theory of gravitation on the grounds that the sun could not act upon the earth as it was not on the earth, by supposing that there must exist an ether that filled up the void between sun and earth and enabled gravity to operate. Mill quoted Newton, himself, as writing:

That gravity should be innate, inherent, and essential to matter, so that one body may act on another, at a distance, through a vacuum, without the mediation of anything else, by and through which their action and force may be conveyed from one to another, is to me so great an absurdity, that I believe no man, who in philosophical matters has a competent faculty of thinking, can ever fall into it. (CW VIII: 754 [V iii §3])

'This passage', Mill continued after the quotation from Newton, 'should be hung up in the cabinet of every cultivator of science who is ever tempted to pronounce a fact impossible because it appears to him inconceivable' (CW VIII: 754 [V iii §3]). Mill then dealt with a string of a priori propositions that did not depend on evidence, e.g.: matter cannot think; space or extension is infinite; nothing can be made out of nothing. His point was that we do not know if these maxims are true or false, but that they are often presumed to be true merely because we think that they must be so. 'A large proportion of all the errors ever committed in the investigation of the laws of nature', he wrote, 'have arisen from the assumption that the most familiar explanation or hypothesis must be the truest' (CW VIII: 756 [V iii §3]).

Mill's discussion of the remaining five fallacies in the category of simple inspection ranged widely from common beliefs to scientific and philosophical theories. He criticized such beliefs as that the lungs of a fox would relieve or cure asthma and that turmeric (which is yellow) was good for jaundice; he rejected the view that some substances bore the 'signatures' of the humours, e.g., red roses of the blood and flowers of saffron for the bile. There were also extensive criticisms of philosophical doctrines associated with 'mysticism' (the Hindu Scriptures, Platonism, and Hegelianism), and also with the Epicureans and Bacon (CW VIII: 757ff. [V iii §4]).

Bain was clearly impressed with Mill's exposition. He regarded Mill as the direct successor to Socrates and Bacon. 'Socrates', he wrote, 'was the first person to urge strongly the natural corruption of the human intellect, and the need of a very severe remedial discipline, which, in the shape of personal cross-examination, he was wont to apply to his fellow Athenians' (Bain 1870: ii.375). From Socrates, Bain moved directly to Bacon, whose discussion of the 'Idols' in the Novum Organum he thought bore a striking resemblance to Mill's discussion of a priori fallacies. 


\section{IV}

Mill's second major distinction was between those fallacies that arose where evidence was distinctly conceived (categories 2-4) and those (category 5) where evidence was indistinctly conceived. He took the name of this last category, 'fallacies of confusion', from Bentham's Book of Fallacies (CW VIII: 742 [V ii §2]; Bentham 1824: 213-58). ${ }^{6}$ Mill stated that this class of fallacy occurred where ' . . the source of error is not so much a false estimate of the probative force of known evidence, as an indistinct, indefinite, and fluctuating conception of what the evidence is' (CW VIII: 809 [V vii §1]). Bain considered this category as 'boundless and indefinable'. 'No man', he wrote, 'can foreshadow the intricacies, the incoherences, the perplexities, the entanglements, possible to the human understanding' (Bain 1870: ii.376). What was considered under this category by Mill was 'extra-logical' and the fallacies could not be absorbed into the main principles of induction and deduction. For Bain, 'a considerable stretch of the logician's province is implied in the taking up of this class of errors' (Bain 1870: ii.375). As with the first category Bain also proposed to consider this one separately, as not wholly part of inductive and deductive logic (Bain 1870: ii.376).

The three classes of examples-ambiguous terms, petitio principii, and ignoratio elenchi - were familiar parts of Aristotle's schema of fallacies in thought (extra dictionem). But Mill's grouping them in this larger category of fallacies of confusion gave them an additional importance, not all of which was captured by Bain's suggestion that they could be separated from the 'boundless and indefinable' mass of fallacies in this category, because they occurred most frequently. Nevertheless, by examining these categories, we shall be able to assess Mill's own objects with this material.

The first of the fallacies was that of ambiguous terms (CW VIII: 809ff. [V vii $\S 1])$. This fallacy occurred in reasoning either when there was an ambiguity in the middle term or when terms were used in different ways in premises and conclusions. To illustrate the range of fallacies under this heading, Mill quoted at length from Whately who provided numerous examples of the fallacy. One was the assumption that words coming from the same root necessarily had the same meaning. Hence, the argument-projectors (entrepreneurs) are unfit to be trusted; this man has formed a project; therefore, he is unfit to be trusted-was fallacious because not everyone who developed a project was a projector. Another fallacy displaying ambiguity in the premise and conclusion might be: To be acquainted with the guilty is a presumption of guilt; this man is so acquainted; therefore, we may presume that he is guilty. Here, there was a difference in the meaning of 'presumption' and 'presume'.

Mill devoted a good deal of attention to numerous confusions in philosophy. One was connected with the term 'theory', whose meanings ranged from 'a completed philosophical induction from experience', which was put into a form 
related to practice so that theory was the explanation of practice. In another and 'more vulgar' sense, theory 'means any mere fiction of the imagination', which attempted to explain how a thing might have been produced rather than explaining how it was produced. When an attempt was made to discredit philosophy, theory and theorists in this latter sense were usually the objects of discussion (CW VIII: 812; [V vii §1]).

The second fallacy was that of petitio principii, begging the question, including reasoning in a circle (CW VIII: 819ff. [V vii §2]). Mill quoted Whately's definition of the fallacy - 'in which the premise either appears manifestly to be the same as the conclusion, or is actually proved from the conclusion, or is such as would naturally and properly be so proved' (CW VIII: 820 [V vii §2]). One example, which Mill took from scholasticism, was that the mind always thinks, because it is the essence of the mind to think (CW VIII: 822-3 [V vii §2]). The conclusion here was the same as the premise and was fallacious also because of the ambiguity in the term 'essence'.

Of the examples where one assumed what was to be proved, Mill drew directly on Bentham's conception of 'question-begging appellatives' in the Book of Fallacies. Bentham argued that although petitio principii was well known to Aristotle, Aristotle had not appreciated how such a fallacy could be committed with the use of a single term (Bentham 1824: 213; CW VIII: 823 [V vii §2]). Mill (and Bentham) used the example of 'innovation' which, when applied to a practice, meant not only novel, but also bad (as opposed to 'improvement' which also meant novel but good) (Bentham 1824: 218). A defender of a new practice could not object to its being called an innovation, but in the process was forced by the use of the term to accept that it was a bad practice and not worthy of defence. Hence, the use of a single word was made to overrule all of the facts and force a major concession from those who defended a practice. ${ }^{7}$

A final example connected with petitio principii was the justification of the doctrine of the social compact or contract in Hobbes and Rousseau, which Mill believed involved reasoning in a circle (CW VIII: 827 [V vii §2]). The social compact was supposedly based on a promise made by one's ancestors. Hence, to the question, why obey the government formed via the social compact, the answer was given that we should do so because of our promise to obey. But Mill argued that the promise to obey was only based on and was enforceable by the social compact itself. Thus, the argument was circular: why obey the social compact? Because we must keep our promise. Why keep our promise? Because we have agreed to the compact (see also Hume 1985: 480ff). Mill pointed out that the argument might have escaped such circularity by the additional argument that the compact was enforceable because of its utility, i.e., it led to happiness and a better life.

The third fallacy was ignoratio elenchi, which consisted of reaching the wrong conclusions from the premises (CW VIII: 827-30 [V vii §3]). This differed from the fallacy of ambiguity, where the meaning of the premises was misconceived, or 
from petitio principii, where the conclusion was mistaken for what was to be proved. Mill again turned to lengthy quotations from Whately to illustrate the fallacy, which used numerous but irrelevant means to defeat an opponent and thereby establish one's own thesis. In his own examples, Mill was more concerned with arguments in philosophy, which he took from Malthus, Berkeley, and others. For example, the argument, that Berkeley's theory of the non-existence of matter could be defeated by knocking one's head against a post, ignored or mistook the fact that Berkeley did not deny the experience of the senses, but that he was sceptical of the underlying cause of the appearances suggested by the senses.

The fallacies of confusion thus ranged widely from public debate to philosophical argument, and from a number of propositions to the deft employment of a single term. In spite of Bain's remark that the number of fallacies of confusion was endless, he believed that the study of logic could provide some discipline to understand and resist them, and the exposure of some of the most obvious categories might have 'a slightly fortifying influence' (Bain 1870: ii.386).

\section{V}

Mill's third distinction among fallacies occurred where evidence was distinctly conceived, as opposed to the category of fallacies of confusion where the evidence was indistinctly conceived. Within this heading he distinguished between inductive and deductive fallacies. For the former (inductive fallacies) he included two categories: fallacies of observation (category 2) and fallacies of generalization (category 3).

Under the heading of fallacies of observation Mill included those arising from non-observation and mis-observation. For the former he distinguished between non-observation arising from overlooking instances and non-observation arising from overlooking circumstances (CW VIII: 773 [V iv §1]). An example of a fallacy arising from overlooking instances was the use of almanacs for predicting the weather. Even though there were many erroneous predictions each year, there were a few correct ones that sustained the faith in almanacs. The false ones were ignored and people continued to stick to the false prophet through the elimination of chance (CW VIII: 774 [V iv §3]). Mill emphasized that the greatest cause of this fallacy was 'preconceived opinion', which led people not to see pertinent and relevant facts. He surveyed a variety of common opinions and scientific theories to demonstrate the widespread use of this fallacy. He pointed to its employment in religious disputes, where texts, which could not be reconciled with one's views, were simply overlooked, and among historians where various events were seen through preconceived opinions to favour Protestants or Roman Catholics, Royalists or Republicans, etc. (see CW VIII: 776-8 [V iv §3]).

The non-observation of circumstances was also shown by Mill to be the source of much fallacious thinking. He showed how the false belief in the phlogistic theory of combustion persisted, because no one looked carefully at the gaseous 
products of combustion. Eventually, chemists were led to the correct explanation that, instead of a substance (phlogiston) being separated and released through combustion, a substance was actually being absorbed. Another example was the widespread use of powders and ointments to effect often miraculous cures when other factors were actually responsible for the cure. Mill mentioned the example of John Wesley who believed he had been cured of a malady by the application of a brown paper plaster of egg and brimstone, and omitted to reckon the importance of four months' rest, with country air, repose, ass's milk, and exercise, also prescribed by his doctor. Another example was the widespread use of mercury in America to cure yellow fever, when those to whom it was applied were already cured of the disease (CW VIII: 778-80 [V iv §4]).

Fallacies based on mal-observation (as opposed to non-observation) arose not from something not seen or ignored, but from something seen wrongly (CW VIII: $782-4$ [V iv §5]). It occurred primarily where one mistook perception for inference. One important example was the opposition to the Copernican system which was based on the common perception of the sun rising and setting and the stars revolving in the heavens. Mill linked to this fallacy the tendency to mistake inferences for intuitions. A visionary might think that God had spoken directly to him or her, and that this was known by intuition. What was at stake, however, was most likely a number of inferences based on mal-observation. In making this assertion Mill was careful to add: 'A caution, therefore, against this class of errors, is not only needful but indispensable; though to determine whether, on any of the great questions of metaphysics, such errors are actually committed, belongs not to this place, but as I have so often said, to a different science' (CW VIII: 784 [V iv §5]). If Mill was reluctant to consider here the great questions of metaphysics and theology, concerned with the existence of God or other supreme principle, he clearly cast doubt on the logical standing of those mystics who claimed direct contact with God on the basis of legitimate inferences from experience.

Fallacies of generalization constituted the second kind of inductive fallacy and the third category in Mill's schema. He stated that these are 'the most extensive of all' fallacies, but if the earlier books of the Logic were followed, the fallacies should not occur and in this category there would only be mistakes and blunders (CW VIII: 785 [V v §1]). He then depicted a number of common examples of types of fallacies that have arisen from a failure to understand and apply the rules of induction.

He began by asserting that certain kinds of generalization must be groundless, because 'experience cannot afford the necessary conditions for establishing them by a correct induction' (CW VIII: 785 [V v §2]). Inferences based on conditions on earth or in the solar system could not be assumed to extend everywhere in the universe. Similarly, despite some exceptions, propositions that asserted a universal impossibility could not be established by induction. 
Among particular fallacies he listed that of mistaking empirical for causal laws (CW VIII: 788-91 [V v §4]). For example, two widely-held beliefs in Mill's day were: as blacks have never been as civilized as whites sometimes were, they shall never be so; and as women were supposed to be inferior to men in intellect, they will necessarily be inferior. These beliefs contained several errors, such as the absence of a comparison of instances or the ascertainment of material facts and the recognition that such instances could not be the basis of causal laws. Another example of this fallacy was that made by 'common-sense' people of a 'practical' disposition who believed that human beings would continue to act as they did at present. These 'common-sense' people wrongly denied the doctrine of the progressiveness of the human species which, despite numerous errors associated with this doctrine, did not assume wrongly that certain behaviour could not occur because it had not previously been exhibited. Mill believed that the doctrine of the progressiveness of the species was an important constituent of social science and though not a cause of anything, it stood as 'a summary expression for the general result of all the causes' (CW VIII: 791 [V v §4]).

Another fallacy consisted of the confusion of sequence with consequence (post hoc, ergo propter hoc - 'after this and therefore owing to this') (CW VIII: 792-4 [V v §5]). As examples Mill listed the following: (1) England owed her industrial pre-eminence to restrictions on commerce; (2) the national debt was a cause of national prosperity; (3) England owed her prosperity to the excellence of the Church, Houses of Parliament, legal procedure, etc. In these examples historical sequences were fallaciously transformed into causal sequences. The fallacy was based on bad generalization a posteriori but could exist a priori with the latter attempting to explain a complicated phenomenon by a simpler theory than its nature admitted. For example, the belief that all disease depended on a hostile acid or alkali in the chemical composition of the body committed this fallacy. In politics there were doctrines that ascribed absolute goodness to particular forms of government, social arrangements, and even to particular modes of education without any reference to stages of civilization and the character of the societies for which they were intended. This became an important theme later in the Logic concerned with the social sciences, but here he discussed aspects of the issues in terms of fallacies.

The remainder of this section was concerned with fallacies associated with analogies and metaphors (CW VIII: 794-801 [V v §§6-7]). These fallacies did not deal with attempts to establish inductions, but operated where a full proof was not a possibility. Mill depicted an argument from analogy as 'an inference that what is true in a certain case, is true in a case known to be somewhat similar, but not known to be exactly parallel, that is, to be similar in all material circumstances' (CW VIII: 794 [V $\vee$ §6]). All that could be expected from analogies was a small increase in probability, and there were ample opportunities for fallacies. 
Metaphors tended to 'assume the proposition which they are brought to prove. ... For an apt metaphor, though it cannot prove, often suggests the proof' (CW VIII: 800 [V v §7]). After considering a number of examples, Mill concluded:

A metaphor, then is not to be considered as an argument, but an assertion that an argument exists; that a parity subsists between the case from which the metaphor is drawn and that to which it is applied. This parity may exist though the two cases be apparently very remote from one another . . . (CW VIII: 801 [V v §7])

The final category (category 4) contained the fallacies of ratiocination and was derived from the distinction between inductive and deductive fallacies (CW VIII: 803-8 [V vi §§1-4]). If inductive fallacies led to fallacies of observation and generalization, deductive fallacies led to fallacies of ratiocination. Mill granted that in the ordinary textbooks of logic fallacies were mainly confined to this category. $\mathrm{He}$, however, devoted only five pages to the topic, referred the reader mainly to discussions in Whately and DeMorgan, and claimed that the rules of the syllogism provided almost complete protection against many of the traditional fallacies (CW VIII: 803 [V vi §1]). ${ }^{8}$ Thus, in a curious way Mill managed to agree with those who rejected the separate study of traditional fallacies on the grounds that one needed to study the rules of logic rather than ways of breaking the rules, while at the same time he developed an extensive and novel treatise on fallacies.

\section{VI}

In the Autobiography Mill characteristically referred to the Logic as supplying the 'opposite doctrine' to the German or a priori school of human knowledge. His doctrine 'derives all knowledge from experience, and all moral and intellectual qualities principally from the direction given to the associations'. The a priori doctrine, 'that truths external to the mind may be known by intuition or consciousness, independently of observation and experience', was considered by Mill 'as the great intellectual support of false doctrines and bad institutions' (CW I: 233). In the Logic Mill particularly sought to clarify the foundations of mathematics and physical science in order to dislodge the a priori school from its supposed foundations. Given his belief that intuitionist philosophy had deleterious effects in 'morals, politics, and religion' (CW I: 233), there may be some justification for Anschutz's remark to the effect that Mill was fighting a political battle through his logical and metaphysical writings (see Anschutz 1953: 61-2; cf. Scarre 1989: 1314). But, as we have seen, there was a second theme in the Logic, amply illustrated in the fifth book, which suggested that logic served truth rather than one doctrine as opposed to another. Indeed, the material on fallacies established how, between opposing doctrines, the truth might be ascertained, presented, and defended. ${ }^{9}$

Mill's subtle and comprehensive study of logical fallacies took the subject away from the realm of deceitful tricks and a source of amusement for students in an otherwise dull subject to oppose false thinking in philosophy, science, morality, 
politics, and many aspects of ordinary life. But such false thinking might also be restated in more valid forms, and, as Mill argued against Whately, the detection of fallacies should be but one aspect of the use of fallacies in logic. The other aspect was an attempt to restate the argument without fallacies, to clarify the argument, and further assess its validity. If, in the essays on Bentham and Coleridge, Mill attempted to bring together the opposing doctrines of the two supposedly leading thinkers of the age, in the Logic he provided the philosophical reader with some of the equipment necessary to restate, clarify, and assess such opposed ideas.

One need not accept Passmore's view that 'there could be no lasting compromise between Mill and the Coleridge school; Coleridge and his followers', he wrote, "were beyond the pale as "intuitionists"-Mill's favourite term of all-encompassing abuse...' (Passmore 1966: 13). Although Mill consistently rejected intuitionism in philosophy, he found much to admire in Coleridge's ideas: the emphasis on the history of countries and institutions as keys to understanding their character, the admiration of Bacon, placing the pursuit of truth above a blind adherence to religious or philosophical creeds, and a willingness to explore opposing poles in thought and politics to determine the truth. This use of opposing points of view enabled Mill to advance what he called in a letter to the Coleridgean, John Sterling, 'a catholic spirit in philosophy' which he felt under 'a special obligation to preach' (CW XIII: 411). Although one might be somewhat puzzled as to how an emphasis on polarities could generate catholicity or universality in philosophy, Mill probably meant simply that by appreciating opposing sides of issues, one could approach more closely to a universal perspective than if one saw the world simply from one perspective. To take a practical example, Mill dealt with the opposing poles in politics of cosmopolitanism on the one hand and nationalism on the other by arguing for a principle of cohesion within society, which did not embrace a hatred of foreigners, an indifference to humanity, or the preference of the national interest over the human race in general. Mill thus attempted to draw from the polarities a new perspective-what has been called 'universalist cosmopolitan patriotism', which was uniquely his and arguably closer to the truth than either cosmopolitanism or nationalism (see Varouxakis 2002: 126).

Mill's account of fallacies and, indeed, the study of logical fallacies generally are not now in fashion. As a faithful follower, Bain, with some exceptions, treated Mill's approach to fallacies in his own study of logic with great respect (see Bain 1870: i. pp. iv-v, ii. 374ff; 1904: 299-300). Nevertheless, many others who followed Mill were not as dutiful. In spite of their widespread critique of Mill's logic, Idealist philosophers wholly ignored the material on fallacies. For F.H. Bradley, Bosanquet, and Green, the truth seemed to dwell in the realm of metaphysics, for which the study of fallacies in Mill's version (and apparently in any other version) was not appropriate (see Bradley 2002, Bosanquet 1895, Green 1886: ii). When H.W.B. Joseph wrote his Introduction to Logic early in the twentieth century, he was not convinced that the study of fallacies should be part of logic. He argued that logic 
was like mathematics and that there were not two ways of thinking about mathematics. If logic was an empirical science, like psychology, one might argue that the study of fallacies was like studying mental illness as a distinct phenomenon within a larger science of psychology (Joseph 1916: 566-7). Nevertheless, Joseph decided to include an 'Appendix' on fallacies and to repeat the traditional thirteen fallacies originally set forth by Aristotle. He justified this move on the grounds that it had tradition in its favour, and would enable students to understand the language of fallacies which remained in common use. 'And if we consider not the enumeration of types of fallacy, but their classification', he wrote, 'it will appear, I think, that there is no such merit in any alternative scheme as justifies us in sacrificing the advantage of keeping to the standard and traditional scheme of Aristotle.' Mill's scheme was consigned to a brief footnote, where a question was raised as to whether or not the a priori fallacies were actually fallacies at all (Joseph 1916: 574 and $\mathrm{n}$ ).

The main opposition to Mill's approach to fallacies, however, came from a different source, which was more indifferent than hostile. This was the development of symbolic logic, and, particularly, the application of algebra to logic. In a recent edition of George Boole's The Mathematical Analysis of Logic, originally published in 1847, just four years after Mill's Logic, the editor has written:

Boole's work freed logicians, once and for all, from the endless repetition of a few principles, mostly derived from Aristotle, and, by example, challenged them to develop their subject in new directions. Many gifted thinkers, among them John Venn, William Stanley Jevons, Charles Sanders Peirce, Ernst Schröder, Alfred North Whitehead, and Bertrand Russell, rose to the challenge, and the vast and autonomous subject of modern logic gradually emerged from their combined efforts. It is a glorious success story. (Boole 1998: xi)

Mill is excluded from this illustrious list of logicians. And few recent textbooks on logic either mention Mill or discuss fallacies generally (see, for example, Tomassi 1999). It is fair to say that modern symbolic logic has moved in new directions. Boole, himself, knew Mill's logic and quoted from him at the beginning of his own work to the effect that where possible the mechanical side of logic might employ a technical notation and where logic did not involve mechanical reasoning, such a technical language should not be employed. Boole accepted this view and wrote that 'to supersede the employment of common reason, or to subject it to the rigour of technical forms, would be the last desire of one who knows the value of that intellectual toil and warfare which imparts to the mind an athletic vigour, and teaches it to contend with difficulties and to rely upon itself in emergencies' (Boole 1998: 2).

Mill, however, did not appear to accept Boole's comment. When he was asked to respond to the work of Jevons, he replied in a letter that, like Boole and DeMorgan, 'he [Jevons] seems to me to have a mania for encumbering questions 
with useless complications, and with a notation implying the existence of greater precision in the data than the questions admit of'. Mill called it 'a vice'-a failure, one supposes, of intellectual virtue. He depicted this vice as 'one preeminently at variance with the wants of the time, which demand that scientific deductions should be made as simple and as easily intelligible as they can be made without ceasing to be scientific' (CW XVII: 1862-3). In a note added in 1856 to the Logic, commenting on the work of De Morgan (CW VII: 171n-3n [II ii §1 note]]), Mill also criticized the use of technical forms in logic as ruling out the study of fallacies, which were concerned with 'the incautious use of the common forms of language'. The consequence was to leave 'the enemy ... in possession of the only ground on which he [the logician] can be formidable' (CW VII: 172n).

Mill's brief comments raise as many questions as they answer (see Scarre 1989: 1ff). It is arguable that the development of symbolic logic, particularly using algebra and grounded in mathematics generally, was more closely linked to modern science than Mill's own approach. From another perspective, however, modern symbolic logic may be regarded as more conventional and traditional than the logic developed by Mill. Arguably, it replaced Mill's logic of truth with the older view of logic as an art aimed at consistency in reasoning. Furthermore, Boole's somewhat stoical comments about logic training the mind, though not foreign to Mill, were more appropriate to the teaching of traditional Aristotelian logic. In place of 'athletic vigour', Mill (in his Inaugural Address) emphasised 'making your mind clear and keeping you from stumbling in the dark over the most outrageous fallacies'. His metaphors evoke Socratic and Platonic themes concerned with illumination and truth. His object was never to develop a gymnasium of the mind but to suggest that logic was the key to truth in science, morality, politics, and religion, and without logic, we were condemned to dwell in error forever. So strongly was he committed to this Socratic doctrine that he extended it, as we have seen, to his defence of liberty generally in society. He frequently invoked the importance of public debate and the study of fallacies as the best way to keep truth alive and opposed to the parade of false philosophical theories. For Mill, the abandonment of the study of fallacies would not only impoverish the mind but also would diminish the concern with truth. In politics one is left with competing ideologies, but with little ambition to transcend them. Mill's account of fallacies restated such Socratic ambitions in a modern idiom. ${ }^{10}$

\section{Notes}

${ }^{1}$ See the Autobiography (CW I: 287), where he wrote concerning the Inaugural Address: ' . . I gave expression to many thoughts and opinions which had been accumulating in me through life $\ldots$...

${ }^{2}$ See Jackson 1941; Anschutz 1953; Ryan 1987; Skorupski 1989; Scarre 1989. For a discussion of Mill on fallacies, see Hansen 1997: 125-43. 
${ }^{3}$ See Sanderson 1618; Aldrich 1691. The Aristotelian and Scholastic fallacies are:

I. Fallacies in language (in dictione):

a) Homonymy (Equivocation): double meaning in a single term.

b) Amphiboly: double meaning in a combination of words or sentences.

c) Conjunction: e.g. because 3 and 2 are 5, it does not follow that 5 is two numbers

d) Disjunction: e.g. 3 and 2 are 5, but one cannot then say that 5 is both an odd and even number.

e) Accentuation: changing the meaning of a sentence by changing the accent on a word, e.g. incense and incense.

f) Figura Dictionis: similar inflections in unlike things, e.g. an African has white teeth and black skin; therefore, he is black and white.

II. Fallacies in thought (extra dictionem):

g) Fallacia accidentis or a dicto simpliciter ad dictum secundum quid: assuming that subject and predicate have their attributes in common; taking a predicate as coextensive with a subject when it is not.

h) Fallacia a dicto secundem quid ad dictum simpliciter: confusion of an absolute statement with a statement limited in manner, place, time, or relation, e.g. what you bought yesterday, you eat today; you bought raw meat yesterday; you eat raw meat today.

i) Ignoratio elenchi: proceeding to argue a different position from that under consideration.

j) Fallacia consequentis, non sequitur: numerous cases of non-sequitur, e.g. rain wets the ground; therefore, wet ground implies that it has rained.

k) Petitio principii: arguing in a circle and begging the question.

1) Non causa pro causa (also post hoc, ergo propter hoc): an inductive fallacy wrongly attributing to causation what merely occurs in sequence.

m) Fallacia plurium interrogationum: asking several questions at once in order to confuse.

See Bain 1870: i.275-8; Grote 1880: 385ff; Aristotle 1955; Hamblin 1970: 52ff.

${ }^{4}$ Coleridge concluded his 'General Introduction, or Preliminary Treatise on Method' which introduced the Encyclopaedia Metropolitana 1845: i.43, as follows: 'Without advocating the exploded doctrine of perfectibility, we cannot but regard all that is human in human nature, and all that in nature is above herself, as together working forward that far deeper and more permanent revolution in the moral world, of which the recent changes in the political world may be regarded as the pioneering whirlwind and storm. But woe to that revolution which is not guided by the historic sense; by the pure and unsophisticated knowledge of the past: and to convey this methodically, so as to aid the progress of the future, has been already announced as the distinguishing claim of the Encyclopaedia Metropolitana.'

${ }^{5}$ The Editors have inserted, following references to the Collected Works of Mill, edition-neutral references, as follows: for the Logic, e.g., "V i §3" means "Book V, Chaper 1, Section 3" and for On Liberty, e.g., "L ii para. 7" means "On Liberty, Chapter 2, Paragraph 7."

${ }^{6}$ The name of this class of fallacy had actually been devised by Étienne Dumont for the earlier French edition of this work. See Bentham 1816: ii.132ff; Bentham 1824: 10.

${ }^{7}$ Bentham's theme here reflected his earlier distinction between eulogistic, dyslogistic, and neutral terminology in A Table of the Springs of Action (1817), where he argued that the estimation of objects, practices, and theories depended in part on the choice and use of terminology. See Bentham 1983: 1-115, esp. 95ff. 
${ }^{8}$ Nevertheless, Mill did consider individually a small number of fallacies of ratiocination. The first was called 'fallacies in the conversion and aequipollency of propositions'. A second was the erroneous conversion of a hypothetical proposition. A third was concerned with changing the premises from one argument to another, and was called in Scholastic philosophy 'a dicto secundum quid ad dictum simpliciter'.

${ }^{9}$ For an example of how fallacies might be applied successfully to metaphysics without challenging any ultimate foundations of an opposing school, see CW IX: 424-7.

${ }^{10}$ On Socrates, see further: Urbinati 2002; Irwin 1998; Riley 1996; Demetriou 1996; Demetriou 1999; Rosen 2004.

\section{References}

Aldrich, H. (1691). Artis Logicae Compendium. Oxford: Oxford University Press.

Anschutz, R.P. (1953). The Philosophy of J. S. Mill. Oxford: Oxford University Press.

Aristotle (1955). On Sophistical Refutations, On Coming-To-Be and Passing-Away, On

the Cosmos. E.S. Forster and D.J. Furley (Trans.). Cambridge, MA and London: The Loeb Classical Library.

Arnauld, A. and Nicole, P. (1996). Logic or the Art of Thinking. J. Vance Buroker, (Ed.).

Cambridge: Cambridge Texts in the History of Philosophy.

Bacon, F. (1994). Novum Organum. P. Urbach and J. Gibson (Trans.). Chicago and La Salle: Open Court

Bain, A. (1870). Logic. 2 vols. London: Longmans \& Co.

Bain, A. (1904). Autobiography. London: Longmans, Green \& Co.

Bentham, G. (1827). Outline of a New System of Logic with A Critical Examination of Dr. Whately's "Elements of Logic". London: Hunt and Clarke.

Bentham, J. (1816). Tactique des assemblées législatives, suivie d'un Traité des sophismes politiques. 2 vols. É. Dumont (Ed.). Geneva and Paris: J.J. Paschoud.

Bentham, J. (1824). The Book of Fallacies: from Unfinished Papers of Jeremy Bentham. By a Friend [P. Bingham]. London: John and H.L. Hunt.

Bentham, J. (1827). Rationale of Judicial Evidence, specially applied to English practice. 5 vols. J.S. Mill (Ed.). London: Hunt and Clarke.

Bentham, J. (1983). Deontology together with A Table of the Springs of Action and Article on Utilitarianism. A. Goldworth (Ed.). Oxford: Clarendon Press.

Bentham, J. (1996). An Introduction to the Principles of Morals and Legislation. J.H. Burns and H.L.A. Hart (Eds.), with a New Introduction by F. Rosen. Oxford: Clarendon Press.

Boole, G. (1998). The Mathematical Analysis of Logic. J. Slater (Ed.). Bristol: Thoemmes Press.

Bosanquet, B. (1895). The Essentials of Logic. London: Macmillan \& Co.

Bradley, F.H. (2002). The Principles of Logic. Uxbridge: Cambridge Scholars.

Demetriou, K. (1996). 'Grote on Socrates: An Unpublished Essay of the 1820s in its Context', Dialogos 3: 36-50

Demetriou, K. (1999). George Grote on Plato and Athenian Democracy: A Study in Classical Reception. Frankfurt: Peter Lang. 
De Morgan, A. (1926). Formal Logic (1847). A.E. Taylor (Ed.). London: The Open Court Company.

Encyclopaedia Metropolitana; or, Universal Dictionary of Knowledge, On an Original Plan (1845). 29 vols. E. Smedley, Hugh J. Rose, and Henry J. Rose (Eds.) London: B. Fellowes et al.

Green, T.H. (1886). The Works of Thomas Hill Green. 3 vols. R L. Nettleship (Ed.). London: Longmans, Green.

Grote, G. (1880). Aristotle, $2^{\text {nd }}$ ed. A. Bain and G. Croom Robertson (Eds.). London: John Murray.

Hamblin, C.L. (1970). Fallacies. London: Methuen.

Hansen, H.V. (1997). 'Mill on inference and fallacies' in D. Walton and A. Brinton (Eds.), Historical Foundations of Informal Logic. Aldershot: Ashgate.

Hobbes, T. (1997). The Collected Works of Thomas Hobbes. 12 vols.W. Molesworth (Ed.) with a New Introduction by G.A.J. Rogers. London: Routledge/Thoemmes.

Hume, D. (1985). Essays, Moral, Political and Literary. E.F. Miller (Ed.). Indianapolis: Liberty Press.

Irwin, T. (1998). 'Mill and the Classical World' in The Cambridge Companion to Mill, J. Skorupski (Ed.). Cambridge: Cambridge University Press.

Jackson, R. (1941). An Examination of the Deductive Logic of John Stuart Mill. London: Oxford University Press.

Joseph, H.W.B. (1916). An Introduction to Logic, $2^{\text {nd }}$ ed. Oxford: Clarendon Press.

Kubitz, O. (1932). 'Development of John Stuart Mill's System of Logic' in Illinois Studies in the Social Sciences, volume 18, nos. 1-2. Urbana, IL: University of Illinois Graduate School.

Locke, J. (1975). An Essay concerning Human Understanding. P. Nidditch (Ed.). Oxford: Clarendon Press.

Malebranche, N. (1997). The Search after Truth. T. Lennon and P. Olscamp (Trans.). Cambridge: Cambridge Texts in the History of Philosophy.

O'Rourke, K. (2001). John Stuart Mill and Freedom of Expression, The genesis of a theory. London: Routledge.

Passmore, J. (1966). A Hundred Years of Philosophy, $2^{\text {nd }}$ ed. London: Duckworth.

Riley, J. (1996). 'On Liberty and the Periclean Ideal', Qwerty 6: 241-8.

Rosen, F. (2003). Classical Utilitarianism from Hume to Mill. London and New York: Routledge.

Rosen, F. (2004). 'J.S. Mill on Socrates, Pericles and the Fragility of Truth', Journal of Legal History 25: 181-94.

Rosen, F. (2006, forthcoming). 'Mill on Coleridge', Telos.

Rosen, F. (2007a, forthcoming). 'From Jeremy Bentham's Radical Philosophy to J.S. Mill's Philosophic Radicalism' in G. Stedman Jones and G. Claeys (Eds.), Cambridge History of Nineteenth Century Political Thought. Cambridge: Cambridge University Press.

Rosen, F. (2007b, forthcoming). 'Parallel Lives in Logic: The Benthams and the Mills'. Volume of essays from the London Mill Conference, April 2006. 
Ryan, A. (1987). The Philosophy of John Stuart Mill, $2^{\text {nd }}$ ed. Basingstoke: Macmillan.

Sanderson, R. (1618). Logicae Artis Compendium, $2^{\text {nd }}$ ed. Oxford: J. Lichfield.

Scarre, G. (1989). Logic and Reality in the Philosophy of John Stuart Mill, Dordrecht: Kluwer Academic Publishers.

Skorupski, J. (1989). John Stuart Mill. London and New York: Routledge.

Tomassi, P. (1999). Logic. London and New York: Routledge.

Urbach, P. (1987). Francis Bacon's Philosophy of Science: An Account and Reappraisal. Chicago and La Salle: Open Court.

Urbinati, N. (2002). Mill on Democracy, From the Athenian Polis to Representative Government. Chicago and London: University of Chicago Press.

Varouxakis, G. (2002). Mill on Nationality. London and New York: Routledge.

Whately, R. (1828). Elements of Rhetoric, $2^{\text {nd }}$ ed. Oxford and London: J. Parker and John Murray.

Whately, R. (1975). Elements of Logic (2 ${ }^{\text {nd }}$ ed., 1927). Ray E. McKerrow (ed.). Delmar, NY:

Scholars' Facsimiles and Reprints.

Frederick Rosen 40 Priory Gardens Highgate

London N6 5QS

United Kingdom

f.rosen@acl.uc.uk 